$12-31-2018$

\title{
The citizens' participation of household solid waste management and monitoring of household solid waste separation in Kelurahan Abadijaya, Kecamatan Sukmajaya, Depok
}

\author{
Zakianis Zakianis \\ Faculty of Public Health, Universitas Indonesia, zakianis@ui.ac.id \\ Pratiwi Koesoemawardani \\ Faculty of Public Health, Universitas Indonesia
}

See next page for additional authors

Follow this and additional works at: https://scholarhub.ui.ac.id/ajce

Part of the Social and Behavioral Sciences Commons

\section{Recommended Citation}

Zakianis, Zakianis; Koesoemawardani, Pratiwi; Fauzia, Sifa; Asror, Muhammad Mustaghfiri; and Ferliana, Erin (2018). The citizens' participation of household solid waste management and monitoring of household solid waste separation in Kelurahan Abadijaya, Kecamatan Sukmajaya, Depok. ASEAN Journal of Community Engagement, 2(2).

Available at: https://doi.org/10.7454/ajce.v2i2.141

Creative Commons License

\section{(c) (i) ()}

This work is licensed under a Creative Commons Attribution-Share Alike 4.0 License.

This Research Article is brought to you for free and open access by the Universitas Indonesia at ASEAN Journal of Community Engagement. It has been accepted for inclusion in ASEAN Journal of Community Engagement. 


\title{
Citizens' participation in household solid waste management and monitoring of household solid waste separation in Kelurahan
}

\author{
Abadijaya, Kecamatan Sukmajaya, Depok

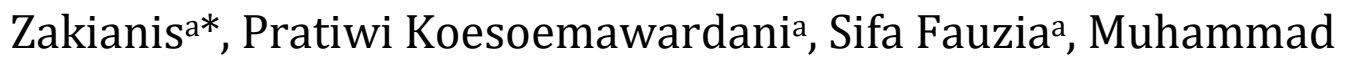 \\ Mustaghfiri Asrora, Erin Ferliana ${ }^{a}$

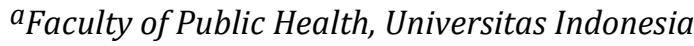

Received: November 14th 2018|| Revised: December 27th || Accepted: December $30^{\text {th }}, 2018$

\begin{abstract}
In Indonesia, sites for TPA (landfills) as final waste dumping are still in limited supply. Meanwhile, the amount of recycled waste is still low due to the lack of awareness about how to sort household waste. The citizens' participation activity for this study aimed to increase awareness about how to sort household waste by involving the stakeholders. The method used for the citizens participation activity was obtained through four stages, including advocacy, counseling for garbage collectors, counseling for households, and monitoring the waste sorting behavior in households. The obtained results are based on a $100 \%$ attendance at counseling by both the stakeholders and the garbage collectors. There is a significance difference in the level of understanding found in households before and after the counseling. According to the results of the study, as many as $44.2 \%$ of the households started sorting their waste based on monitoring.
\end{abstract}

Keywords: Waste, management, household, sorting, counseling, monitoring

\section{Introduction}

The change in citizens' lifestyles in Indonesia also caused the change in waste composition. The solid waste that now comes from settlement areas is larger than from areas; that is, as much as 55-65\% more (United States Environmental Protection Agency, 2009). In Indonesia, plastic waste composition increased from 8\% in 2001 to $14 \%$ in 2015 (Ministry of Environment and Forestry Republic of Indonesia, 2016). Unfortunately, the increased composition of solid waste was not balanced by the available solid waste handling. Therefore, most solid waste handling is done by open dumping in landfills. By the year 2020, landfills in Indonesia (called Tempat Pembuangan Akhir or TPA) will be required to use larger pieces of land, as many as $1610 \mathrm{~m} 2$ (Ministry of Environment and Forestry Republic of Indonesia, 2015).

\footnotetext{
*Correspondence Author: zakianis@ui.ac.id
} 
Zakianis, Pratiwi Koesoemawardani, Sifa Fauzia, Muhammad Mustaghfiri Asror, Erin Ferliana | ASEAN Journal of Community Engagement | Volume 2, Number 2, 2018

In Indonesia, the management of solid waste consists of handling and reducing waste (Law of Republic of Indonesia No. 18 Year 2008). In handling household solid waste, waste collectors only handled 24\% (National Institute of Health Research and Development, Indonesian Ministry of Health, 2018). The way to manage solid waste is to reduce it, using the concept of 3Rs (reduce, reuse, and recycle). Up until now, recycled solid waste only accounts for 7\% of the total (Ministry of Environment and Forestry Republic of Indonesia).

In Indonesia, the 3R waste management unit does reduce solid waste and the waste bank. Indonesia's 3R-based waste management unit is known as Tempat Pengolahan Sampah berbasis 3R-Reduce, Reuse, and Recycle (TPS3R). TPS3R and the waste bank have different procedures. The main difference is in the sorting stage. Solid waste is sorted according to whether it is biodegradable and non-biodegradable. Generally, biodegradable solid waste is processed into compost, while non-biodegradable solid waste with economic value is sold, and its residue is dumped in a landfill. Every household, store, and market that puts their solid waste in TPS3R is charged according to their TPS3R regulation.

The method is totally different with the waste bank system. The waste bank requires households, stores, offices, and other solid waste producers to sort their solid waste first, specifically to separate biodegradable solid waste from non-biodegradable solid waste with economic value. Then, households sell their solid waste to the waste bank. The waste bank member receives an appropriate amount of money for their solid waste (Retno \& Suryani, 2015; Halimatussadiah et al., 2016).

Indonesia has a large population (Dhokhikah et al., 2015) but limited funds for managing solid waste (Permana et al., 2015). Therefore, citizens' participation is vital. The government should also continuously stimulate change (Permana et al., 2015; Fujii, 2008). Citizens' participation includes reducing solid waste by sorting it to increase the amount of recycled waste (De Feo \& De Gisi, 2010; Babaei et al., 2015) and to pay the solid waste retribution (Zurbrügg, 2003).

An Indonesian city with a population of 2.1 million people as of 2016, Depok has both TPS3R and a waste bank (Depok Statistics, 2018). Since 2014, Depok has regulated the management of solid waste. To conform with regulations, Depok local government provides resources and facilities to support the solid waste sorting program called waste 
Zakianis, Pratiwi Koesoemawardani, Sifa Fauzia, Muhammad Mustaghfiri Asror, Erin Ferliana | ASEAN Journal of Community Engagement | Volume 2, Number 2, 2018

treatment unit or Unit Pengolahan Sampah (UPS). The working mechanism of UPS is the same as for TPS3R. Depok has 30 active UPS units and 408 waste banks. Depok has only one landfill, TPA Cipayung, which is over its capacity for solid waste; therefore it will be closed in 2013 and the final processing of the solid waste will be moved to another place (Malau, 2018).

The other problem in Depok is that most citizens are still not sorting their waste, which causes an obstacle in managing the solid waste. Therefore, sorting solid waste is the key to the solid waste managing process, which is expected to solve Depok's solid waste problem.

In order to help the Depok government reduce solid waste generation in the landfill, the Directorate of Research and Community Sevices Universitas Indonesia (Direktorat Riset dan Pengabdian Masyarakat - DRPM UI) and Faculty of Public Health Universitas Indonesia (Fakultas Kesehatan Masyarakat-FKM UI), along with the Environment and Hygiene Office of Depok City (Dinas Lingkungan Hidup and Kebersihan - DLHK Depok) conduct a community service program for household solid waste management.

\subsection{Integrated and sustainability waste management}

In developed country, the waste management is ignored so often because there were hunger issues, health issues, the limited supply of water, unemployment issues, and civil war. As a result, most of the citizens in developed country are lived in settlement without waste management as well (Chandrappa \& Das, 2012). However, globally, there are urge and effort to introduce the $3 \mathrm{R}$ concept including reduce, reuse, and recycle, therefore it affects in reducing the waste in TPA (Shekdar, 2009). In order to solve the problem of waste, managing the waste should be sustainable and integrated.

The sustainability waste management is focusing on the importance of reducing the waste, reusing the waste, and recycling the waste in hierarchy of waste management (United States Environmental Protection Agency, 2017). Meanwhile, the integrated waste management is term of reference to design and apply a systematic and comprehensive of waste management system that affected by various factors such as waste management elements consisted of producing waste and reducing the waste, sorting, collecting, carrying, processing, recycling, and dumping the final waste (Guerrero et al., 2013; Tchobanoglous \& Kreith, 2002; Chandrappa \& Das, 2012). The waste management 
Zakianis, Pratiwi Koesoemawardani, Sifa Fauzia, Muhammad Mustaghfiri Asror, Erin Ferliana | ASEAN Journal of Community Engagement | Volume 2, Number 2, 2018

elements are affected by various factors too, such as legal aspect, institution aspect, financial aspect, technical aspect, social culture aspect, environmental aspect, and stakeholders' involvement, all that aspects will affect the continuity of waste management (Appiah et al., 2013; Guerrero et al., 2013; United Nations Environment Program, 2005).

The involvement of the stakeholders takes big roles in integrated and sustainable waste management. A modern waste management needs role segmentation and clear responsibility within the stakeholders. The government is participated in jurisdiction and is responsible in policy in comprehensive for waste management. The other stakeholder is only following determined policy (United Nations Environment Program, 2005). The stakeholders that involved in waste management are the people or organization (government) (Shekdar 2009), the households (Sujauddin 2008), the international government, private sector, non-governmental organization (NGO), Minister of Health, Minister of Environment, Minister of Finance, and recycling industry (Chandrapa \& Das Bhusan, 2012; Guerrero et al., 2013; Tchobanoglous \& Kreith, 2002).

In zero waste program, known as 3R (Reduce, Reuse, Recycle), is needed to add fourth $\mathrm{R}$, is Responsible. Responsibility is a key of sustainability. The responsibility is including individual/household responsibility, community responsibility, industrial responsibility, professional responsibility, and government responsibility (Connett, n.d.). All the stakeholders have their own roles and responsibilities in 3R (reduce, reuse, and recycle) based-waste management (Niyati, 2015).

The central government is participated in increasing citizens' participation, such as provide legal protection, finance need, and citizens awareness. Meanwhile, the local government is participated in increasing the citizens' participation in recycling the waste as the part of waste management and is participated as facilitator by encourage the waste management and build the cooperation with the other sectors (Damanhuri \& Padmi, 2010).

Despite the government plays a dominant role in providing management waste service, the government cannot self-supporting without organization support. Yet, if the management waste program is only surrounded to the society as the main object, they cannot execute the program without government and private sector help. The society active participation is the first step in creating well governance. Therefore, waste management needs well cooperation among parties, such as the society, the government, 
Zakianis, Pratiwi Koesoemawardani, Sifa Fauzia, Muhammad Mustaghfiri Asror, Erin Ferliana | ASEAN Journal of Community Engagement | Volume 2, Number 2, 2018

and private sector. The interaction process among parties is as important as service quality. In fact, the government capability and support is very limit, while the society demanding the best quality service (Mappasere \& Idris, 2016).

The society role in 3R-based waste management system is sorting and recycling the waste (Damanhuri \& Padmi, 2010). Yet, the sorting and recycling activity need a support from government, as like as monitoring the recycling activity. Therefore, some households are unwilling to sort the waste by laziness (32,5\%) (Dhokhikah et al., 2015). To solve this laziness, then the garbage collector plays an important role, such us through monitoring the sorting activity among the households (Bernstad 2015). The garbage collector can warn the households when they are not sorted their waste. The warning may include written or spoken warning (Sheau-ting et al., 2016).

Thus, the garbage collector plays an important role to support sorting waste activity within the households. While the institution plays to increase the ability of garbage collector in monitoring the sorting/recycling activity among society. The local government can provide a training to the garbage collector about how to increase collecting activity efficiency, sorting, and recycling the waste. The training material may include working efficiency, sorting efficiency, the use of self-protector equipment, or other material according to term and condition (United Nations Human Settlements Programme, 2010).

\subsection{Theory of behavioral change}

There has been so many theory explaining the relation mechanism within environment behavior and its related factor, such as the Theory of Reasoned Action (TRA) and the Theory of Planned Behavior (TPB). That theories explained a basic theory about willingness toward the environment in physiological, social, and behavior point of view (behavioristics) (Yang et al., 2011).

The use of physiological model is important to obtain the reaction nor factor that support the household to sort or recycle their waste. Therefore, sorting and recycling the waste need more effort in certain people as the part of the households which the waste should be sorted, prepared, or deposited. Consequently, the decision in sorting the waste is possible becoming complex factor and is needed to be considered (Ghani et al., 2013). 
Zakianis, Pratiwi Koesoemawardani, Sifa Fauzia, Muhammad Mustaghfiri Asror, Erin Ferliana | ASEAN Journal of Community Engagement | Volume 2, Number 2, 2018

According to Theory of Reasoned Action (TRA) that developed by Fisbein and Azjen (1975), self-behavior is influenced by the willingness (intention). Yet, for years, some previous study using TRA showed that a willingness is not always showed a real behavior (Amini et al., 2014; Chu \& Chiu, 2003). TRA is not considered uncontrolled factors beyond person that affects individual willing and behavior.

Therefore, Azjen in 1988, was completed TRA becomes Theory of Planned Behaviour (TPB). In TPB, Azjen was added some incomplete construction in TRA, such us perceived self-control (perceived behavior control/PCB) or in other word, Azjen was considered uncontrolled factors beyond person (Glanz et al., 2008). In previous study, so many researchers used TPB Theory in health-behavioral study, including sorting or recycling waste behavior (Ghani et al., 2013; Bernstad, 2014; Martin et al., 2006; Tonglet et al., 2004; Amini et al., 2014; Chu \& Chiu, 2003; Zhang et al., 2015; Akil et al., 2015; Babaei et al., 2015).

Yet, Tonglet et al. (2004) stated that TPB Theory is only used for intention test toward sorting and recycling waste behavior, consisted of three components such as the attitude, subjective norm, and PCB that could not describe past experience about recycling and its performance because the lack of precise opportunity, source, and skill.

In order to increase the waste sorting-skill, a counselling about waste management is important. An environment understanding could be described as the individual obtains an environmental awareness, knowledge, skill, value, and experience to solve environmental problems including the waste (Everett, n.d.). The environment understanding can increase self-motivation among individual (Yang et al., 2011; Ekere, Mugisha, \& Drake, 2009).

According to waste management and behavioral change theory, the activity of citizens' participation involves all the stakeholders such as Environment and Sanitation City Office, $\mathrm{RT} / \mathrm{RW} /$ cadre, the garbage collectors, and the households. Thus, this community service activity aims to reduce the solid waste in the landfill through integrated household solid waste management. This program is expected to be able to increase the sorting solid waste in the household. This sorted solid waste in the household shall be carried out separately then can be processed in UPS therefore the solid waste in Cipayung landfill will be decreased. 
Zakianis, Pratiwi Koesoemawardani, Sifa Fauzia, Muhammad Mustaghfiri Asror, Erin Ferliana | ASEAN Journal of Community Engagement | Volume 2, Number 2, 2018

\section{Methods}

\subsection{Study Sites}

The community service is the result of collaboration between DRPM UI and FKM UI with DLHK Depok and other government officials in Kelurahan Abadijaya. The area of the community service was completed in RW. 01/RT. 11 and 12 at Kelurahan Abdijaya, Kecamatan Sukmajaya, Depok. This community service was conducted from June to October 2018.

\subsection{Respondents}

The target for this community service was all the district/sub-district governments, solid waste collectors, and households at RT. 11 and 12, RW. 01 in Kelurahan Abadijaya, Depok. The total respondents were 253, including stakeholder advocates numbering as high as 22 people. The training for garbage collectors included 11 people, and the counseling for households about how to sort the waste in RT. 11 and RT. 12 included as many as 220 households.

\subsection{Stages of activity}

FKM UI and DRPM UI were responsible for providing counseling about reducing and sorting the solid waste, and about monitoring the solid waste sorting activity in RT. 11 and 12 , as well as for providing counseling to the solid waste collectors in RW. 01 regarding carrying solid waste separately. DLHK Depok was responsible for providing facilities for sorted solid waste. Biodegradable solid waste is carried to UPS to process into compost. The waste collector can sell non-biodegradable solid waste with economic value to the waste bank. Meanwhile, DLHK Depok carries the residue to TPA Cipayung.

The community service was done in four stages: advocacy, counseling for waste collectors and households, and monitoring household solid waste sorting activities. Before and after counseling the citizens of RT. 11/12, tests were held to obtain the understanding of solid waste management, including the definition of solid waste, the impact of the reduce, reuse, and recycle plan, and the types of solid waste. The counseling included books and leaflets consisting of information about household solid waste sorting management (biodegradable, non-biodegradable, and residue). After the counseling, a 
Zakianis, Pratiwi Koesoemawardani, Sifa Fauzia, Muhammad Mustaghfiri Asror, Erin Ferliana | ASEAN Journal of Community Engagement | Volume 2, Number 2, 2018

post test was held to obtain RT. 11 and 12 citizens' levels of understanding about solid waste sorting management.

Table 1. The Stages of Community Engagement Activity

\begin{tabular}{|c|c|c|c|c|}
\hline Stages & $\begin{array}{l}\text { Aims and } \\
\text { activities }\end{array}$ & Time & Target & Goals \\
\hline Advocacy & $\begin{array}{l}\text { The aim: } \\
\text { To ensure the } \\
\text { continuity of the } \\
\text { program and to } \\
\text { provide facilities } \\
\text { to utilize the } \\
\text { sorted waste } \\
\text { The activity: } \\
\text { FKM UI held a } \\
\text { meeting with the } \\
\text { stakeholders in } \\
\text { RW 01 district } \\
\text { office, Abadijaya } \\
\text { district in a } \\
\text { month before the } \\
\text { counseling for } \\
\text { households }\end{array}$ & $\begin{array}{l}\text { May-July 2018, } \\
\text { did advocacy and } \\
\text { organized } \\
\text { permits }\end{array}$ & $\begin{array}{l}\text { 1. DLHK } \\
\text { Depok } \\
\text { 2. Officials } \\
\text { 3. RW and RT } \\
\text { 4. Socialite } \\
\text { 5. Cadres in } \\
\text { RT } 11 \text { and } \\
\text { 12/RW } 01\end{array}$ & $\begin{array}{l}70 \% \text { of } \\
\text { stakeholder } \\
\text { s attended in } \\
\text { advocacy }\end{array}$ \\
\hline $\begin{array}{l}\text { The } \\
\text { counselin } \\
\text { g for } \\
\text { carrying } \\
\text { sorted } \\
\text { solid } \\
\text { waste }\end{array}$ & $\begin{array}{l}\text { The aim: } \\
\text { Increase the } \\
\text { ability of solid } \\
\text { waste collectors } \\
\text { to carry sorted } \\
\text { solid waste } \\
\text { The activity: } \\
\text { FKM UI held } \\
\text { solid waste } \\
\text { collector training } \\
\text { for RW } 01 \\
\text { Kelurahan } \\
\text { Abadijaya. The } \\
\text { counseling was } \\
\text { held in the } \\
\text { afternoon after } \\
\text { the waste } \\
\text { collectors } \\
\text { finished their } \\
\text { work at 15.00- } \\
\text { 17.00 in RW } 01\end{array}$ & $\begin{array}{l}\text { August 2018, } \\
\text { held solid waste } \\
\text { collector training } \\
\text { RW } 01 \text { district } \\
\text { office, Kelurahan } \\
\text { Abadijaya, } \\
\text { Kecamatan } \\
\text { Sukmajaya, } \\
\text { Depok }\end{array}$ & $\begin{array}{l}\text { The waste } \\
\text { collector of RW } \\
01 \text { Kelurahan } \\
\text { Abadijaya, } \\
\text { Kecamatan } \\
\text { Sukmajaya, } \\
\text { Depok }\end{array}$ & $\begin{array}{l}70 \% \text { of } \\
\text { waste } \\
\text { collectors } \\
\text { attended the } \\
\text { counseling } \\
\text { on how to } \\
\text { sort solid } \\
\text { waste }\end{array}$ \\
\hline
\end{tabular}


Zakianis, Pratiwi Koesoemawardani, Sifa Fauzia, Muhammad Mustaghfiri Asror, Erin Ferliana | ASEAN Journal of Community Engagement | Volume 2, Number 2, 2018

\begin{tabular}{lllll}
\hline Stages & $\begin{array}{c}\text { Aims and } \\
\text { activities }\end{array}$ & Time & Target & Goals \\
\hline & $\begin{array}{l}\text { district office, } \\
\text { Kelurahan } \\
\text { Abadijaya }\end{array}$ & & \\
& &
\end{tabular}

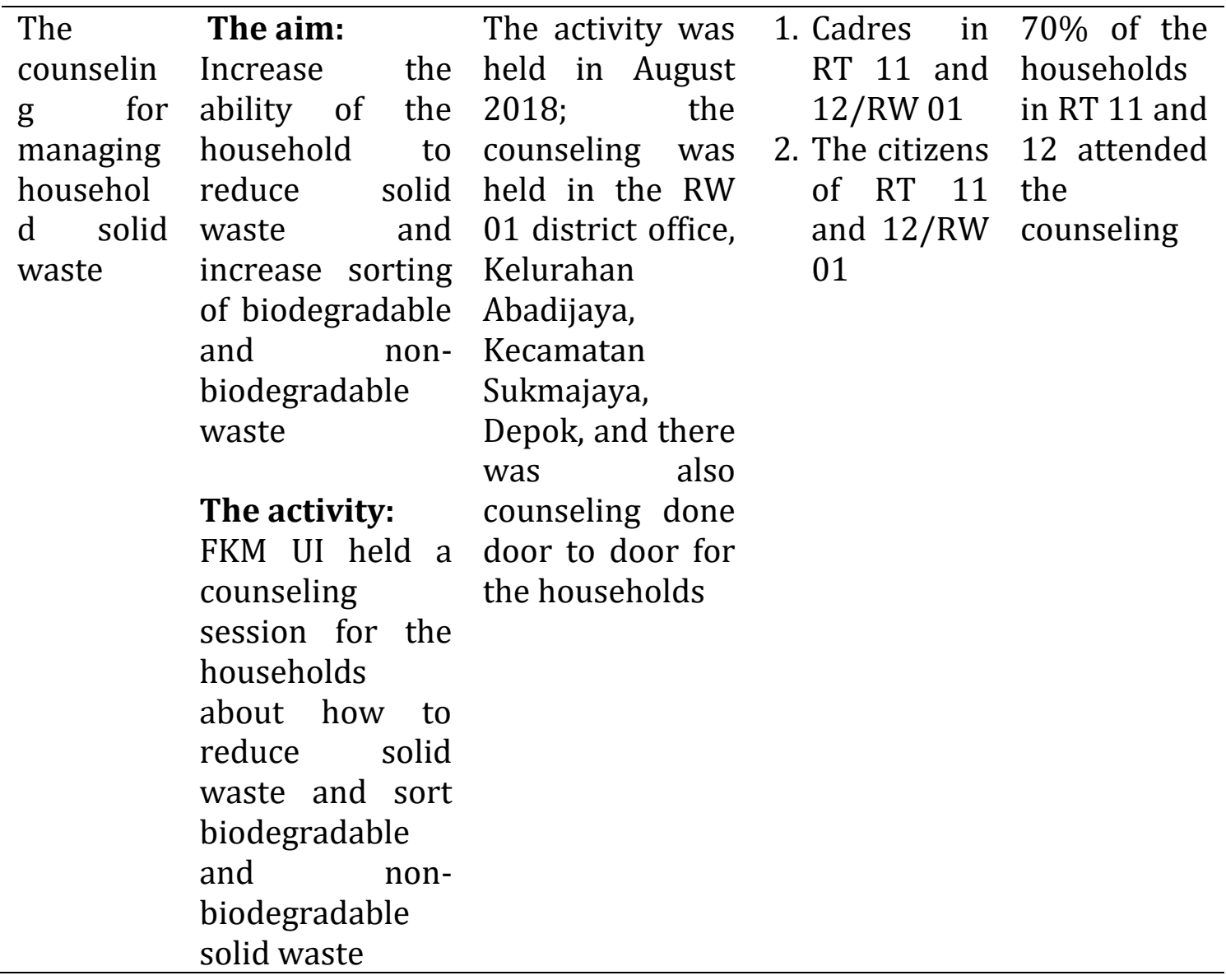


Zakianis, Pratiwi Koesoemawardani, Sifa Fauzia, Muhammad Mustaghfiri Asror, Erin Ferliana | ASEAN Journal of Community Engagement | Volume 2, Number 2, 2018

\begin{tabular}{|c|c|c|c|c|}
\hline Stages & $\begin{array}{l}\text { Aims and } \\
\text { activities }\end{array}$ & Time & Target & Goals \\
\hline $\begin{array}{l}\text { Monitorin } \\
\text { g the } \\
\text { househol } \\
\text { d sorting } \\
\text { solid } \\
\text { waste } \\
\text { activity }\end{array}$ & $\begin{array}{l}\text { The aim: } \\
\text { Control the } \\
\text { households for } \\
\text { sorting the solid } \\
\text { waste and } \\
\text { control the solid } \\
\text { waste collectors } \\
\text { for sorting the } \\
\text { solid waste } \\
\text { The activity: } \\
\text { The cadre } \\
\text { monitored the } \\
\text { sorting activity } \\
\text { of the } \\
\text { households and } \\
\text { the solid waste } \\
\text { collectors. The } \\
\text { solid waste is } \\
\text { carried out three } \\
\text { times a week } \\
\text { (Tuesday, } \\
\text { Thursday, and } \\
\text { Saturday) }\end{array}$ & $\begin{array}{l}\text { The activity was } \\
\text { done in } \\
\text { September 2018. } \\
\text { The monitoring } \\
\text { activity in } \\
\text { sorting the } \\
\text { household solid } \\
\text { waste by the } \\
\text { solid waste } \\
\text { collector was } \\
\text { done by the } \\
\text { cadre. }\end{array}$ & $\begin{array}{c}\text { The } \\
\text { households }\end{array}$ & $\begin{array}{l}\text { 1. As many } \\
\text { as } 30 \% \text { of } \\
\text { the } \\
\text { househol } \\
\mathrm{d} \text { already } \\
\text { sorted } \\
\text { their solid } \\
\text { waste } \\
\text { correctly } \\
\text { 2. } 100 \% \text { of } \\
\text { the waste } \\
\text { collectors } \\
\text { were } \\
\text { already } \\
\text { carrying } \\
\text { out the } \\
\text { correct } \\
\text { sorting of } \\
\text { solid } \\
\text { waste }\end{array}$ \\
\hline
\end{tabular}

\subsection{Data Analysis}

Descriptive statistics were used to present the household characteristics in tables; then the difference between the understood values among households before and after the counseling was obtained by correlation testing.

\section{Result and Discussion}

\subsection{Advocacy}

The advocacy was obtained two months before the counseling took place. The advocacy was held by all the stakeholders (DLHK Depok, the cadres, the head of RW/and other socialites) in Depok, especially RT. 11 and 12 RW. 01 Kelurahan Abadijaya. In its implementation, $100 \%$ of the stakeholders attended the advocacy.

This public service approached stakeholders to maintain the sustainability of the household waste management program that had been implemented. This was in line with other studies that mentioned the stakeholder approach as of the main ways to influence 
Zakianis, Pratiwi Koesoemawardani, Sifa Fauzia, Muhammad Mustaghfiri Asror, Erin Ferliana | ASEAN Journal of Community Engagement | Volume 2, Number 2, 2018

citizens (Kwek Wei Ling and Wei Da, 2018). The advocacy implementation was targeted to reach 70\%; however, it reached $100 \%$ because all stakeholders were present. The success of the $100 \%$ stakeholder attendance is credited to conducted the activity during working time, sending invitation letters to all stakeholders, and the stakeholders scheduling this activity in advance.

The advocacy activity accomplished several agreements:

a. The households should sort their waste and still pay tuition fees as high as Rp25,000 for RT. 12 and Rp20,000 for RT. 11, and they should also collect their waste.

b. The sorted waste in the households will be carried out separately by the garbage collector in RW. 11 and will be gathered and put in an agreed-upon place.

c. The easy foul waste will be carried out to UPS by the garbage collector and will be processed for compost by DLHK, Depok. The waste residue will be carried out to TPA by DLHK Depok.

d. The non-easy foul waste with economic value will be sold and the proceeds will be given to the garbage collectors.

The accomplished agreement is appropriate because, according to the previous study, it was the citizens' participation in waste management that reduced the waste production (Squires, 2006), sorted the waste, recycled the waste, processed it into compost, made handcrafted items from the waste (Dhokhikah et al., 2015; Permana et al., 2015; Barr, 2007), and paid the retribution. As the local government, DLHK plays an important role in providing facilities and infrastructure to process the easy foul waste into compost.

\subsection{Household Solid Waste Management Counseling on The Solid Waste Collection Staff}

The counseling activity for the solid waste collector officers was held on August 7, 2018 at Balai RW. 01, Kelurahan Abadijaya. All 11 officers attended the counseling session (100\%). All of the solid waste collector officers were male, with an average age of 53 years. Most of the officers graduated from middle school and earned approximately Rp1,500,000.00 per month.

The success of this counseling for the collection staff happened in part because the counseling was conducted in the afternoon, after all collection staff had finished their jobs. Before this activity took place, the head of RW had informed all officers about the 
Zakianis, Pratiwi Koesoemawardani, Sifa Fauzia, Muhammad Mustaghfiri Asror, Erin Ferliana | ASEAN Journal of Community Engagement | Volume 2, Number 2, 2018

counseling. All officers were involved in this counseling and training activity for managing household solid waste. Previous research suggested that solid waste management activities would not succeed if there was no awareness by various parties, one of which was the solid waste collector officers (Widayatno and Vitasari, 2009).

\subsection{Household Solid Waste Management Counseling for RT 11 and 12 Citizens}

The average age of respondents for this community service activity in RT 11 was 43 years old, with a minimum age of 16 and a maximum age of 78 years. The average age of respondents in RT. 12 was 48 years old, with a minimum age of 21 years old and a maximum age of 68. The average income of respondents in RT. 11 was Rp4,419,300.00, with a minimum income of Rp300,000.00 and a maximum income of Rp25,000,000.00. Most respondents in RT. 12 had an average income of Rp4,727,800.00, with a minimum income of $\mathrm{Rp} 1,000,000.00$ and a maximum income of $\mathrm{Rp} 20,000,000.00$. Most of the participants in this community service counseling activity were female, middle-school educated, and held entrepreneurial jobs where the average income was more than Rp3,000,000.00 each month (see Table 2).

Table 2. Household Characteristics in RT 11 and 12, RW 01 Kelurahan Abadijaya, Sukmajaya, Depok City in 2018

\begin{tabular}{|c|c|c|c|}
\hline \multirow[b]{2}{*}{ Variable $(n=155)$} & \multicolumn{2}{|c|}{ Frequency (\%) } & \multirow{2}{*}{$\begin{array}{c}\text { Total n (\%) } \\
\begin{array}{c}\text { n=220 } \\
(\%)\end{array}\end{array}$} \\
\hline & $\begin{array}{c}\text { RT 11 } \\
\text { n=166 } \\
(\%)\end{array}$ & $\begin{array}{c}\text { RT } 12 \\
\text { n=54 } \\
(\%)\end{array}$ & \\
\hline \multicolumn{4}{|l|}{ Sex } \\
\hline Male & 26.5 & 7.4 & 21.8 \\
\hline Female & 73.5 & 92.6 & 78.2 \\
\hline \multicolumn{4}{|l|}{ Educational background } \\
\hline Uneducated & 4.2 & 3.7 & 4.1 \\
\hline Elementary school & 10.8 & 7.4 & 10 \\
\hline Middle school & 66.9 & 68.5 & 67.3 \\
\hline High school & 18.1 & 20.4 & 18.6 \\
\hline \multicolumn{4}{|l|}{ Occupation } \\
\hline Jobless & 17.2 & 20.4 & 10.4 \\
\hline $\begin{array}{l}\text { Military/Policeman/Civil } \\
\text { servant/Worker }\end{array}$ & 30.7 & 35.2 & 31.8 \\
\hline Enterpreneur & 52.4 & 31.5 & 47.3 \\
\hline Farmer/Labor & 4.2 & 9.3 & 15.5 \\
\hline Others (school) & 5.4 & 3.7 & 15 \\
\hline
\end{tabular}


Zakianis, Pratiwi Koesoemawardani, Sifa Fauzia, Muhammad Mustaghfiri Asror, Erin Ferliana | ASEAN Journal of Community Engagement | Volume 2, Number 2, 2018

\begin{tabular}{|c|c|c|c|}
\hline \multirow[b]{2}{*}{ Variable $(n=155)$} & \multicolumn{2}{|c|}{ Frequency (\%) } & \multirow{2}{*}{$\begin{array}{c}\text { Total n (\%) } \\
\begin{array}{c}\text { n=220 } \\
(\%)\end{array}\end{array}$} \\
\hline & $\begin{array}{c}\text { RT } 11 \\
\mathrm{n}=166 \\
(\%)\end{array}$ & $\begin{array}{c}\text { RT } 12 \\
\text { n=54 } \\
(\%)\end{array}$ & \\
\hline \multicolumn{4}{|l|}{ Earnings } \\
\hline$<$ Rp3,000,000 & 41.6 & 37 & 40.5 \\
\hline$\geq \mathrm{Rp} 3,000,000$ & 58.4 & 63 & 59.50 \\
\hline
\end{tabular}

Household solid waste management counseling for solid waste sorting was proposed to RT. 11 and 12 RW. 1 Kelurahan Abadijaya citizens. In RT.11, 64\% of citizens joined the counseling. In RT. 12 RW.1, 67.5\% of citizens joined the counseling.

The household solid waste management counseling activity for RT. 11 and 12 citizens did not reach the targeted indicator of $70 \%$. This was because there was difficulty in gathering all household members at one specific time, and the households asked for a door to door counseling to be conducted instead. The lack of human resources available to give the door to door counseling, as well as citizens who were difficult to find, made this counseling method fail. This failure also occurred because there were some household members who were unwilling to join the household solid waste counseling activity for unknown reasons. However, household members who did join the counseling program became more attentive and increased their knowledge. This was because door to door counseling allowed citizens to be more focused and conducive to understanding the counseling material presented. The results of other studies mentioned that the solid waste management process-based community empowerment using a door to door method would allow citizens to pass obstacles and difficulties more than presenting solutions in a community service program (Teguh Sulistiyani d Wulandari, 2017).

Counseling on community activities demonstrated an increased knowledge of household solid waste management once held on RT. 11 and 12. The knowledge level on RT. 11 increased from an average level of 82.2 before counseling to 89.7 after counseling. The knowledge level also increased on RT. 12 from 82.87 before counseling to 98.15 after counseling. This counseling activity also showed a difference in respondents' knowledge levels against household solid waste management before and after the counseling activity (see Table 3). Pengetahuan mengenai cara mengurangi sampah, memilah sampah sangat penting karena pengetahuan dapat meningkatkan motivasi dari dalam untuk memilah sampah. Untuk meningkatkan pengetahuan pengelolaan sampah dapat dilakukan melalui penyuluhan (Yang et al., 2011; Ekere, Mugisha, \& Drake, 2009). 
Table 3. Respondent knowledge level before and after household solid management counseling on RT. 11 and 12, RW. 01, Kelurahan Abadijaya, Sukmajaya, Depok in 2018

\begin{tabular}{ccccccc}
\hline \multicolumn{2}{c}{ Respondent } & Mean & Median & $\begin{array}{l}\text { Standard } \\
\text { Deviation }\end{array}$ & Min-Max & P value \\
\hline \multirow{2}{*}{ RT. 11 } & Pre-test & 82.2 & 85 & 8.429 & $65-100$ & 0.00 \\
& Post test & 89.7 & 90 & 7.731 & $55-100$ & \\
\multirow{2}{*}{ RT. 12 } & Pre-test & 82.87 & 85 & 8.333 & $60-100$ & 0.00 \\
& Post test & 98.15 & 100 & 4.586 & $80-100$ & \\
\hline
\end{tabular}

The result of one month's periodic household solid waste management monitoring by officials and cadres of RT. 11 and RT. 12, RW. 01, Kelurahan Abadijaya showed that the average percentage of citizens participating in biodegradable and non-biodegradable solid waste sorting was $43.5 \%$ on RT. 11 , and $44.9 \%$ on RT. 12 . Household solid waste sorting activities tended to fluctuate, indicating that the activity monitoring should be done continuously (see Table 4).

The solid waste collector officers conducted monitoring activities once a week. Based on the successive target, $100 \%$ of officers succeeded in collecting the solid waste using the sorting method, while $30 \%$ of the household members who joined the counseling succeeded in implementing the solid waste sorting method. The success with this activity occurred because there was advocacy by the stakeholders, as well as because the solid waste collector officers and citizens were contacted before the program was implemented. Previous research suggested that activities using a stakeholder approach and citizens' mentoring and monitoring for household solid waste management were the main reason for success in maintaining the sustainability and strength of citizens' sorting abilities (Kwek Wei Ling and Wei Da, 2018).

According to a previous study, a household's sorting waste behavior increases if an officer is controlling the effort (Sheau-ting et al., 2016; Zhang \& Wen, 2014; De Feo \& De Gisi, 2010). In Japan, sorted waste is placed into transparent plastic bags to allow the officer to check it more easily (Niyati, 2012). Another previous study from Kota Tembilahan showed that without the government's role in monitoring household waste management, citizens' participation stayed very low. In fact, $100 \%$ of respondents stated that the local government never monitored waste management (Mulyadi et al., 2010). 
Zakianis, Pratiwi Koesoemawardani, Sifa Fauzia, Muhammad Mustaghfiri Asror, Erin Ferliana | ASEAN Journal of Community Engagement | Volume 2, Number 2, 2018

Table 4. Waste sorting activity monitoring by waste collector officers in RT. 11 and 12,

RW. 01, Kelurahan Abadijaya, Sukmajaya, Depok in 2018

\begin{tabular}{|c|c|c|c|c|c|c|}
\hline \multirow{4}{*}{ RT } & \multirow{4}{*}{$\begin{array}{l}\text { Household } \\
\text { members } \\
\text { joining } \\
\text { counseling }\end{array}$} & \multicolumn{5}{|c|}{ Household waste sorting activity monitoring } \\
\hline & & \multirow{2}{*}{\multicolumn{4}{|c|}{$\begin{array}{c}\begin{array}{c}\text { Household waste sorting } \\
\text { frequency }(\%)\end{array} \\
\text { Week }\end{array}$}} & \multirow{3}{*}{$\begin{array}{l}\text { Average total of } \\
\text { household members } \\
\text { sorting the solid } \\
\text { waste }(\%)\end{array}$} \\
\hline & & & & & & \\
\hline & & 1 & 2 & 3 & 4 & \\
\hline RT 11 & 166 & 50 & 47 & 37.9 & 39.1 & 43.5 \\
\hline RT 12 & 54 & 70.4 & 37 & 55 & 40.7 & 44.9 \\
\hline Total & 220 & 55 & 44.5 & 42.3 & 39.9 & 44.7 \\
\hline
\end{tabular}

\subsection{Advantages and disadvantages of the program}

This community service program activity certainly had both advantages and disadvantages. The advantages of the household solid waste management program included minimizing the solid waste volume in landfills based on sorting biodegradable solid waste from non-biodegradable sold waste. Non-biodegradable solid waste also had economic value, which was then allocated to the waste bank. This program also made the collection of household solid waste more efficient because collection time decreased. Citizens perceived advantages including an increased knowledge in how to manage household solid waste and increased awareness about how to change behaviorally to manage the environment.

The disadvantage of this program was the small coverage of implementation, as there were limited human resources for monitoring and educating citizens.

\subsection{Obstacles of the Activity}

Significant awareness about sorting household solid waste had not been high, and confidence in sorting solid waste was still low due to incorrect sorting, indicating that the program was not yet supported by all citizens. This also occurred when the door to door counseling activity was conducted. Citizens lacked focus when given materials, and some household members were difficult to find at home as house doors were always closed.

\section{Conclusion}

As much as $70 \%$ stakeholder advocacy was targeted for this program implementation. However, the target was exceeded at $100 \%$ because all stakeholders were present. Solid 
Zakianis, Pratiwi Koesoemawardani, Sifa Fauzia, Muhammad Mustaghfiri Asror, Erin Ferliana | ASEAN Journal of Community Engagement | Volume 2, Number 2, 2018

waste collector officers had already reached the successive targeted indicators, with $70 \%$ of officers present for the counseling. Meanwhile, when the counseling activity was conducted, $100 \%$ of officers were present (11 officers). However, the citizens counseling on RT. 11 and 12 only reached the target of $60 \%$. Educated citizens had an increased knowledge about household solid waste management. Household solid waste sorting activity monitoring also exceeded the target, with $100 \%$ of waste collector officers succeeding in transporting the sorted solid waste, and $30 \%$ of the household members following the counseling advice on how to sort waste.

\section{Acknowledgements}

The community service team would like to thank those who supported the implementation of this community service as well as writing this book. This public service was fully funded by Universitas Indonesia public service grants number 4701/UN2. R3.1/HKP.05.00 /2018.

\section{References}

Babaei, A.A. et al. 2015. Household recycling knowledge, attitudes and practices towards solid waste management. Resources, Conservation and Recycling, 102(SEPTEMBER), pp.94-100.

Barr, S. 2007. Factors Influencing Environmental Attitudes and Behaviors: A U.K. Case Study of Household Waste Management. Environment and Behavior, 39(4), pp.435473.

Ekere, W., Mugisha, J. \& Drake, L. 2009. Factors influencing waste separation and utilization among households in the Lake Victoria crescent, Uganda. Waste Management, 29(12), pp.3047-3051. Available at: http://dx.doi.org/10.1016/j.wasman.2009.08.001.

De Feo, G. \& De Gisi, S. 2010. Domestic separation and collection of municipal solid waste: Opinion and awareness of citizens and workers. Sustainability, 2(5), pp.1297-1326.

Depok Statistics. 2018. Total Population in Depok City Year 2016. Depok: Depok Statistics.

Fujii, Y. 2008. Successful Source Separation in Asian Cities: Lessons from Japan's Experience and an Action Research in Thailand, Tokyo. Available at: 
Zakianis, Pratiwi Koesoemawardani, Sifa Fauzia, Muhammad Mustaghfiri Asror, Erin Ferliana | ASEAN Journal of Community Engagement | Volume 2, Number 2, 2018

https://www.researchgate.net/publication/237520706_Successful_Source_Separ ation_in_Asian_Cities_Lessons_from_Japan's_Experience_and_an_Action_Research_i n_Thailand.

Halimatussadiah, A., Widyawati, D. \& Syahril, S. 2016. Trust, Leadership, and Money Incentives and the Promotion of Participation in Community-Based Recycling Activity: Which One Works? Phillippines.

Kwek Wei Ling, T. and Wei Da, L. 2018. [online] Clc.gov.sg. Available at: https://www.clc.gov.sg/docs/default-source/commentaries/a-softer-approachto-managing-waste.pdf [Accessed 15 Oct. 2018].

Law of Republic of Indonesia No. 18 Year 2008 concerning Waste Management.

Malau, B.S.L. 2018. Penutupan TPA Cipayung di Depok Direncanakan Tahun Depan. Warta Kota.

Ministry of Environment and Forestry Republic of Indonesia. 2016. PENUTUPAN PEKAN LINGKUNGAN DAN KEHUTANAN INDONESIA 2015 RANGKAIAN HLH 2015DIALOG., pp.1-5.

Mulyadi, A., Husein, S. \& Saam, Z. 2010. Perilaku masyarakat dan peranserta pemerintah daerah dalam pengelolaan sampah di kota tembilahan. Ilmu Lingkungan, 3(2), pp.147-162. Available at: http://ejournal.unri.ac.id/.

National Institute of Health Research and Development, Indonesian Ministry of Health. 2018. Riset: 24 Persen Sampah di Indonesia Masih Tak Terkelola. [Online] Available at: $\quad$ http://litbang.kemendagri.go.id/website/riset-24-persen-sampah-diindonesia-masih-tak-terkelola/ [Accessed 11 November 2018].

Niyati, M. 2015. A Comparative Study of Municipal Solid Waste Management in India and Japan. The Gakken Research Papers, 25.

Permana, A.S. et al. 2015. Sustainable solid waste management practices and perceived cleanliness in a low-income city. Habitat International, 49, pp.197-205.

Retno, D. \& Suryani, S. 2015. Waste Bank as Community-based Environmental Governance: A Lesson Learned from Surabaya. Procedia - Social and Behavioral Sciences, 184(August 2014), pp.171-179. Available at: http://dx.doi.org/10.1016/j.sbspro.2015.05.077. 
Zakianis, Pratiwi Koesoemawardani, Sifa Fauzia, Muhammad Mustaghfiri Asror, Erin Ferliana | ASEAN Journal of Community Engagement | Volume 2, Number 2, 2018

Sheau-ting, L., Sin-yee, T. \& Weng-wai, C. 2016. Preferred Attributes of Waste Separation Behaviour: An Empirical Study. Procedia Engineering, 145, pp.738-745. Available at: http://dx.doi.org/10.1016/j.proeng.2016.04.094.

Squires, C.O. 2006. PUBLIC PARTICIPATION IN SOLID WASTE MANAGEMENT IN SMALL ISLAND DEVELOPING STATES,

Teguh Sulistiyani, A. and Wulandari, Y. 2017. Proses Pemberdayaan Masyarakat Desa Sitimulyo, Kecamatan Piyungan, Kabupaten Bantul dalam Pembentukan Kelompok Pengelola Sampah Mandiri. Indonesian Journal of Community Engagement, 02.

United Nations Human Settlements Programme. 2010. Solid Waste Management in the World's Cities, London and Washington DC.

United States Environmental Protection Agency. 2009. Municipal Solid Waste Generation, Recycling, and Disposal in the United States: Facts and Figures for 2009. EPA United States Environmental Protection Agency, pp.1-12.

Widayatno, T. and Vitasari, D. 2009. Penyuluhan Pengolahan Limbah Pertanian dan Sampah Rumah Tangga di Desa Demangan Kecamatan Sambi Kabupaten Boyolali. publikasiilmiah.ums.ac.id, [online] 12(1410-9344). Available at: https://publikasiilmiah.ums.ac.id/bitstream/handle/11617/1162/6975.pdf; sequence $=1$

Yang, L., Li, Z.S. \& Fu, H.Z. 2011. Model of Municipal Solid Waste Source Separation Activity: A Case Study of Beijing. Journal of the Air \& Waste Management Association, 61(November), pp.157-163.

Zhang, H. \& Wen, Z.-G. 2014. Residents' Household Solid Waste (HSW) Source Separation Activity: A Case Study of Suzhou, China. Sustainability, 6, pp.6446-6466. 